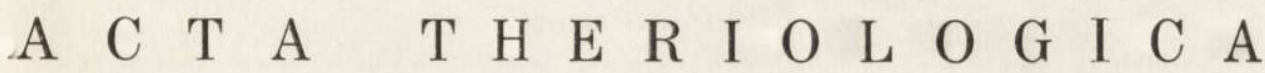 \\ VOL. XVII, 1: 1-24. \\ BIAEOWIEŻA \\ May, 1972
}

John A. S E A L A N D ER

\section{Circum-annual Changes in Age, Pelage Characteristics and Adipose Tissue in the Northern Red-backed Vole in Interior Alaska}

[With 11 Figs]

\begin{abstract}
Circum-annual changes in age, pelage characteristics and adipose tissue were measured in the northern red-backed vole, Clethrionomys rutilus dawsoni (M erriam), from July, 1963 through August, 1964 in the environs of College, Alaska $\left(65^{\circ} \mathrm{N} 147^{\circ} \mathrm{W}\right)$. By midwinter older age classes disappeared from the population and did not constitute a significant portion of the population until the following May and June. In July recruitment of younger age classes, resulting from spring breeding, into the population shifted it to a predominantly young-aged one, and by August most of the older age classes representing overwintered mice had apparently died off. Hair weight in $\mathrm{mg} / \mathrm{cm}^{2}$ was minimal in July, $1963\left(10.6 \mathrm{mg} / \mathrm{cm}^{2}\right)$ and maximal in December, $1963\left(18.9 \mathrm{mg} / \mathrm{cm}^{2}\right)$, an over-all increase of $78 \%$. Mean dry skin weight in $\mathrm{mg} / \mathrm{cm}^{2}$ was almost the reciprocal of hair weight. Coat color change was measured in percent reflectance at different wave lengths. Lowest reflectances representing dull, summer pelages were noted in July and August and highest reflectances representing bright, winter and spring pelages were noted in December and January. Pelts were fully prime from November through February marking the end of the fall and the beginning of the spring molts respectively. The pattern of the fall and spring molts was reversed. Relative wet pelt weight and skinfold thickness showed similar trends with peaks in early winter and spring. Relative dry pelt weight was rather constant throughout the years except during the rapid molt period in spring. Interscapular brown fat increased in mass relative to net body weight by $154 \%$ from July to January, but the index of white fat remained relatively constant except for a rise in early winter before hair density or brown fat reached maximum levels. Ingestion rate, measured as gastrointestinal fill, showed an apparent sharp increase early in winter and again in spring.
\end{abstract}

\section{INTRODUCTION}

Morphological, physiological and behavioral adjustments to low winter temperatures are necessary for continued existence of small mammal populations in high, subarctic latitudes. Changes in pelage characteristics 
and in kind and amount of fat reserves are especially important for survival since small subarctic mammals must make both insulative and metabolic adjustments to compensate for severe climatic changes, particularly temperature, which they encounter in winter.

This paper reports circum-annual variations in age, pelage characteristics and fat reserves in the northern red-backed vole, Clethrionomys rutilus dawsoni (M e r riam). The principal objective of the study was to measure some of the alterations in body components, such as fur and fat, which contribute to the over-all seasonal acclimatization of this species to climatic conditions that prevail in its natural habitat during both summer and winter.

\section{MATERIALS AND METHODS}

Red-backed voles were captured in the environs of College, Alaska $\left(65^{\circ} \mathrm{N}, 147^{\circ}\right.$ W) in 1963 and 1964. Habitats from which the voles were trapped, trapping methods and autopsy procedures have been desciribed elsewhere (S e a l an der, 1966).

Only animals classed as adults (based on live weight, body measurements, pelage characteristics and reproductive condition) were used. Juvenile or immature voles were either released when captured or added to a laboratory colony for use in other studies.

Voles vere weighed to the nearest $0.1 \mathrm{~g}$ on a Shadograph balance. The weight of ingesta was subtracted from the gross weight to obtain net body weight $(N B W)$. Pelts were weighed on a torsion balance to the nearest $0.01 \mathrm{~g}$, and smaller organs and tissues, such as brown fat and hair, were weighed on a microtorsion balance accurate to $0.5 \mathrm{mg}$.

Before removing the pelt, skinfold thicknesses were measured in the midbody region at the middorsal and midventral line. The fold of skin was measured to the nearest $0.1 \mathrm{~mm}$ with a Vernier caliper. As a substitute for spring-loading, the Vernier jaws were enclosed with a rubber band so that they closed firmly bu: opened without applying undue force.

The pelt (minus tail and skin covering the feet to wrists and ankles) was removed without stretching after making a midventral incision from lower jaw to base of tail. After weighing it was flattened out on a smooth piece of cardboard and dried for $4-5$ days. When dry the pelt was carefully stripped from the cardboard leaving a very thin layer of subdermal connective tissue and associated fat adhering to the cardboard. Most pelts thus removed were dry and relatively fat-free. Subcutaneous fat was mostly absorbed into the cardboard, and remaining fat in the pelt was extracted with petroleum ether. After drying and defatting, pelts were placed in a dessicator for 48 hours or more until the weight stayed relatively constant. Most recorded weight losses were attributed to water loss, although a small part of the weight losses were due to loss of connective tissue and fat.

Procedures described below were used to determine monthly changes in pelage primeness, hair density and color. These measurements provided information about seasonal molts and insulative properties of the pelage.

Outlines of each pelt were drawn on tracing paper and pigmented (unprime) areas on the flesh side of each flat skin (areas with melanin concentration in active 
follicles of unerupted hairs) were traced in the outlines. The area of each whole pelt and of the unprime portions was determined by planimetry and primeness was expressed as a percentage by subtracting the percentage of pigmented portions from 100. The incidence of completely unpigmented (fully prime) pelts, expressed as a percentage, occurring in each month was also determined.

A middorsal sample, $8 \mathrm{~cm}^{2}$, of each pelt was removed with a round punch for measurement of hair weight per unit area of pelt. After weighing the samples, the hair was removed from one-half of each monthly series with a depilatory cream (Nair) containing Ca thioglycolate. Depilated samples were oven dried at low heat and reweighed. Hair weight in milligrams represents the weight difference in each sample before and after depilation and is expressed as $\mathrm{mg} / \mathrm{cm}^{2}$ of pelt. Dry skin weight is similarly expressed as $\mathrm{mg} / \mathrm{cm}^{2}$ of pelt.

Reflectivity was measured on the remaining one-half of the undepilated pelage samples. Two procedures were used. Reflectance values for the primary colors perceived by the eye (amber, green, blue) were determined with a Color-Coder (Automatic Control Devices, Inc.) and are expressed as mean values for each color for each month. Reflectivity was also measured with a Bausch and Lomb Spectronic 505 Recording Spectrophotometer using procedures like those of Selander, Johnston \& Hamilton (1964) and Smith et al. (1969). With this instrument wave length was automatically varied from $400-700 \mathrm{~m} \mu$ (violet to red) while the sample was simultaneously compared against a pressed white magnesium carbonate standard. Eight equally spaced wave lengths between 400 and $700 \mathrm{mu}$ were used in analyzing seasonal pelage color changes.

Approximate ages of mice were determined from root growth and crown wear of the first lower molars $\left(M_{1}\right)$. Age criteria used were mainly those employed by Mazák (1963) and $\mathrm{Haitlinger} \mathrm{(1965)} \mathrm{for} \mathrm{C.} \mathrm{glareolus} \mathrm{but} \mathrm{with} \mathrm{modifications}$ based on other investigators work (Prychodko, 1951; Z Zjda, 1961, 1964; Smyth, 1966; Pucek, Ryszkowski \& Zejda, 1969; Lowe, 1971; Viitala, 1971). Mazák observed that $\mathrm{M}_{1}$ roots began to develop as late as three and one-half months of age whereas Prychodko concluded that molar root development begins as early as two and one-half months of age. Also it is possible that root development proceeds faster in spring than autumn ( $\mathrm{Zej} \mathrm{da}, 1961)$. $\mathrm{Z}$ ejda (1964) believes that the late root development observed by Mazák was due to growth retardation under laboratory conditions and used the value of three months as the beginning of $\mathrm{M}_{1}$ root development. This value was adopted in the present study.

Skulls were first cleaned by dermestid larvae. The roots of $M_{1}$ in the ramus of the lower jaw were then exposed with a fine dental drill working under low pover magnification with a stereo microscope.

Crown wear proved not as useful in age determination as root growth. The exposed crown height above the alveolar surface ranged from about $0.6-0.8 \mathrm{~mm}$. The total crown height decreased from the estimated age of three months on, but there was no noticeable change in the exposed crown height except in voles more than one year old.

Six age classes based on $\mathrm{M}_{1}$ root development and crown wear were established. These are described below and shown in Figure 1.

Class I - no evidence of roots; pulp cavity wide open with irregular edges; too h high crowned and showing essentially no wear; alveolar bone less compact than in older age classes - age about $1-3$ months. 
Class II - short roots one-fifth or less the depth of the ramus of the mandible from the alveolar surface; pulp cavity open; tooth high crowned and showing little wear; alveolar bone firmly embedded around roots - age about 3-6 months.

Class III - roots longer, one-fourth to one-third depth of ramus of the mandible; pulp cavity open; height of tooth crown reduced by wear; alveolar bone firmly embedded around roots - age about 6-10 months.

Class IV - root length from one-half to three-fourths depth of mandible; pulp cavity closed or nearly closed; height of tooth crown reduced by wear; alveolar bone firmly embedded around roots - age about 10-12 months.

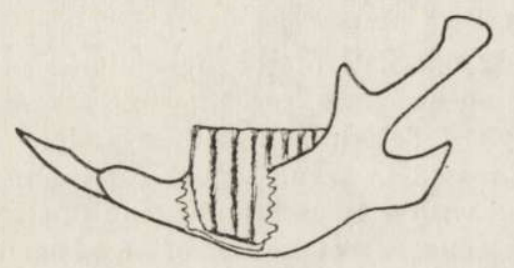

I
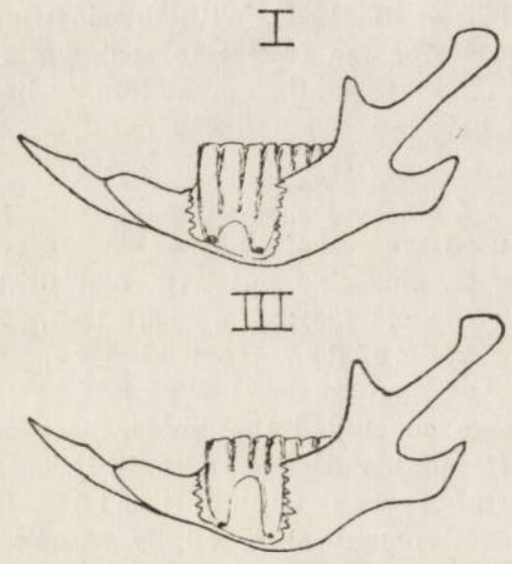

V

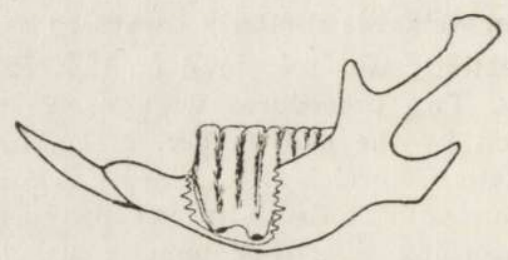

II
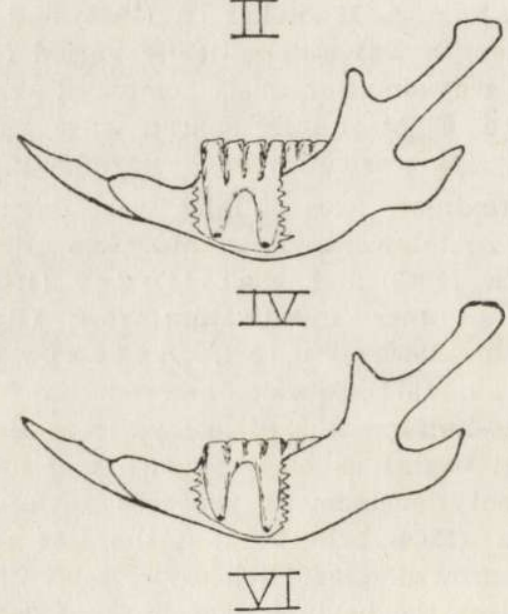

Fig. 1. First lower molar $\left(\mathrm{M}_{1}\right)$ of Clethrionomys rutilus of various ages. Lateral views of exposed teeth. Approximate ages are: I - 1-3 months, II - 3-6 months, III $-6-10$ months, IV $-10-12$ months, V $-12-18$ months, VI $-18-24$ months.

Class V - root length over three-fourths depth of mandible; pulp cavity mostly closed; tooth crown shows considerable wear; open spaces in alveolar bone around roots - age about $12-18$ months.

Class VI - root length nearly equal to depth of mandible; pulp cavity closed; crowns of teeth low, flattened and cupped by wear; alveolar bone around roots spongy, forming a cavity around roots - age about 18-24 months.

The height of the tooth crown is not a reliable age indicator except in older voles since the actual crown height above the jaw surface decreases very little 
with age, and tooth enamel ridges must be almost completely worn down before a conspicuous decrease in height of the tooth crown above the jaw ramus is apparent (as in very old individuals). Most voles in the population die before this degree of tooth wear becomes evident.

In the proposed classification of age groups Class I corresponds roughly to Haitlinger's groups I and II and Class II to his groups III and IV. Some overlap exists between Class III and his groups IV and V. Class IV is equivalent to his graup VI and Classes V and VI to his group VII. The age classification based on tooth structure used in the present study while not as precise as that of $\mathrm{M}$ a zák (1963) and $\mathrm{Zejda}(1961,1964)$ is considered adequate to deal with the sample sizes involved. As pointed out by $\mathrm{H}$ a itlinger (1965), too exact classification when not dealing with a large series of specimens may obscure the natural picture with respect to age structure of the population.

The interscapular brown adipose tissue $(B A T)$ depot was excised from the scapular depression in the dorsal thoracic region, trimmed free of major blood vessels and white fat, if present, and weighed fresh. Cervical and thoracic $B A T$ depots were not removed, and the interscapular $B A T$ depot is presumed to reflect changes in the total amount of BAT seasonally.

Index numbers were assigned to designate estimated amounts of white fat as follows: 0 , none visible; 1 , light, mostly subcutaneous; 2, moderate subcutaneous, light visceral; 3 , moderate subcutaneous and visceral; 4, heavy subcutaneous and visceral; 5 , obese.

\section{RESULTS}

\section{Population Age Structure}

The approximate age composition of the population for the period January, 1964 through August, 1964 is presented in Figure 2. Skulls were not saved for age analysis for the period June, 1963 through December, 1963, and for this period inferences only can be drawn from the 1964 data.

The age composition of the College, Alaska population corresponded in a general way to that of the Wrocław, Poland population of C. glareolus for the same months ( $\mathrm{H}$ a it $\mathrm{ling}$ e r, 1965). A strict comparison is not possible because red-backed voles in Poland were of a different species and continued to produce litters even into December whereas reproduction ceased by late August or early September in Alaskan voles (S e a lander, 1966) thereby increasing the percentage of older age classes in the winter and spring population through lack of recruitment in younger age classes. Also the Wrocław population age structure was based on pooled data from several years and included very young animals that could be classed as subadults or juveniles, in contrast to my data based on part of one year which excluded juveniles and immatures.

In Alaska young adults in class I comprised the bulk of the July and 
August population. If the age structure of the Alaska population from September through December is roughly similar to that of the Wrocław population, it might be expected that during this period age classes I, II, and III would predominate with age class I dropping out in December through lack of recruitment as breeding ceases in autumn. Thus the average age of Alaskan voles during this period would be less than that

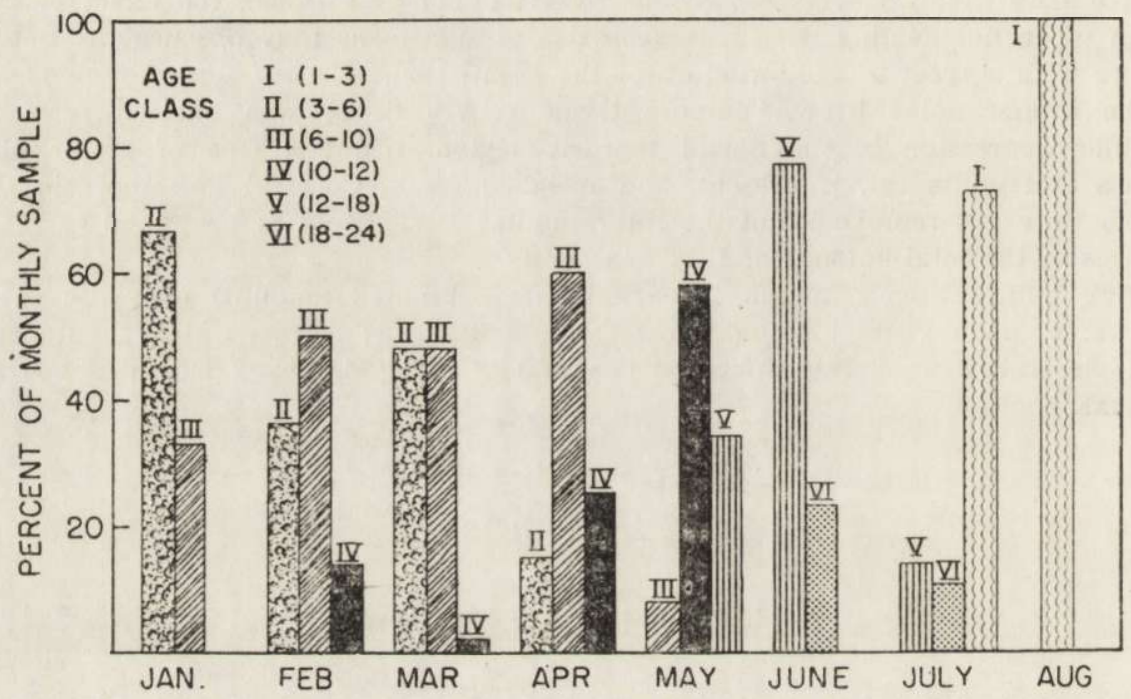

Fig. 2. Population age structure of adult red-backed voles in the environs of College, Alaska in 1964. Juveniles and immatures are excluded from the monthly samples. Approximate ages in months for the different age classes are shown in parentheses.

of the Polish population due to the later onset of spring breeding activities. Haitlinger captured pregnant females at the end of March and noted that the youngest voles appeared as early as April, although the first young ones were not actually caught until May. The earliest date that I captured a pregnant female was 12 May, and I caught no juvenile or immature voles until about mid-June. This indicates that the higher latitude Alaskan population of C. rutilus was probably about $4-6$ weeks out-of-phase reproductively with the Polish population of $C$. glareolus.

Figure 2 shows that there was a progressive shift from younger to older age classes from January until July, much like Haitlinger's observations. Recruitment of young animals into the population probably began about early or mid-June, although Figure 2 does not show this since juveniles and immatures were excluded from the monthly samples. 


\section{Pelage Changes}

Color. Seasonal dichromatism is marked in the red-backed vole and bright winter and dull summer pelage phases are easily distinguished. Changes in pelage color are, however, gradual rather than abrupt when

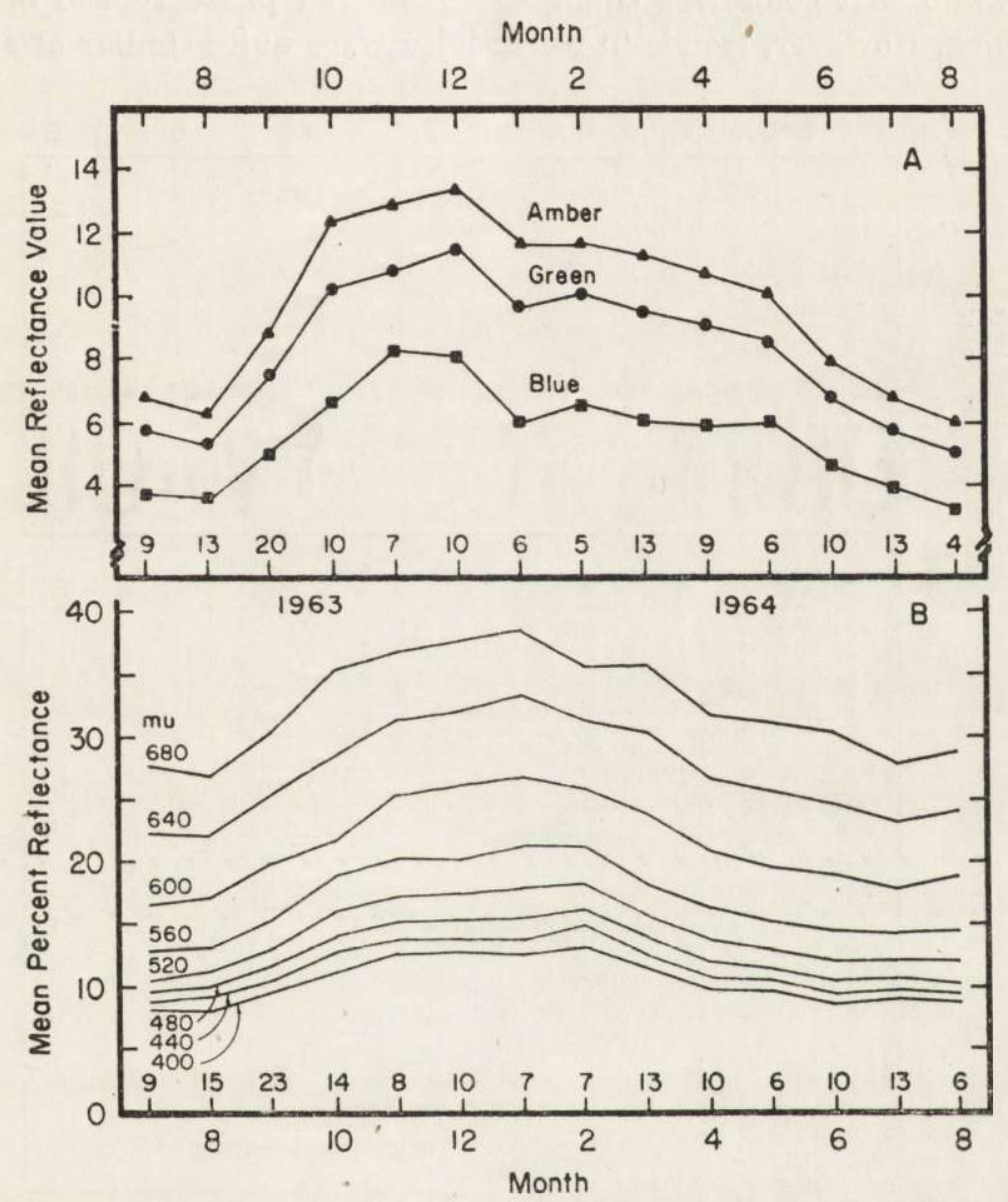

Fig. 3. Seasonal variations in mean reflectance values for the middorsal pelage of Clethrionomys rutilus from College, Alaska. (A) Color-Coder values using amber, green and blue filters. (B) Reflectance as a function of wave length from 400 $700 \mathrm{mu}$ (violet to red) measured with a B \& L Spectronic 505 Spectrophotometer. Sample sizes are indicated below the means.

measured throughout the year. As Figure 3 shows, reflectances increased between October and November and pelage brightness continued to increase until December and January when a decline began which continued through spring and summer. Reflectance values reached a low 
point and leveled off about June. Slight increases, especially in longer wave lengths, were apparent between July and September. Winter and summer values, especially in longer wave lengths, were significantly different (P .01-.001).

Reflectances were greatest near the red end of the spectrum, especially when coat color was changing to the red phase typical of winter and spring. However, trends in reflectivity were quite similar at all wave

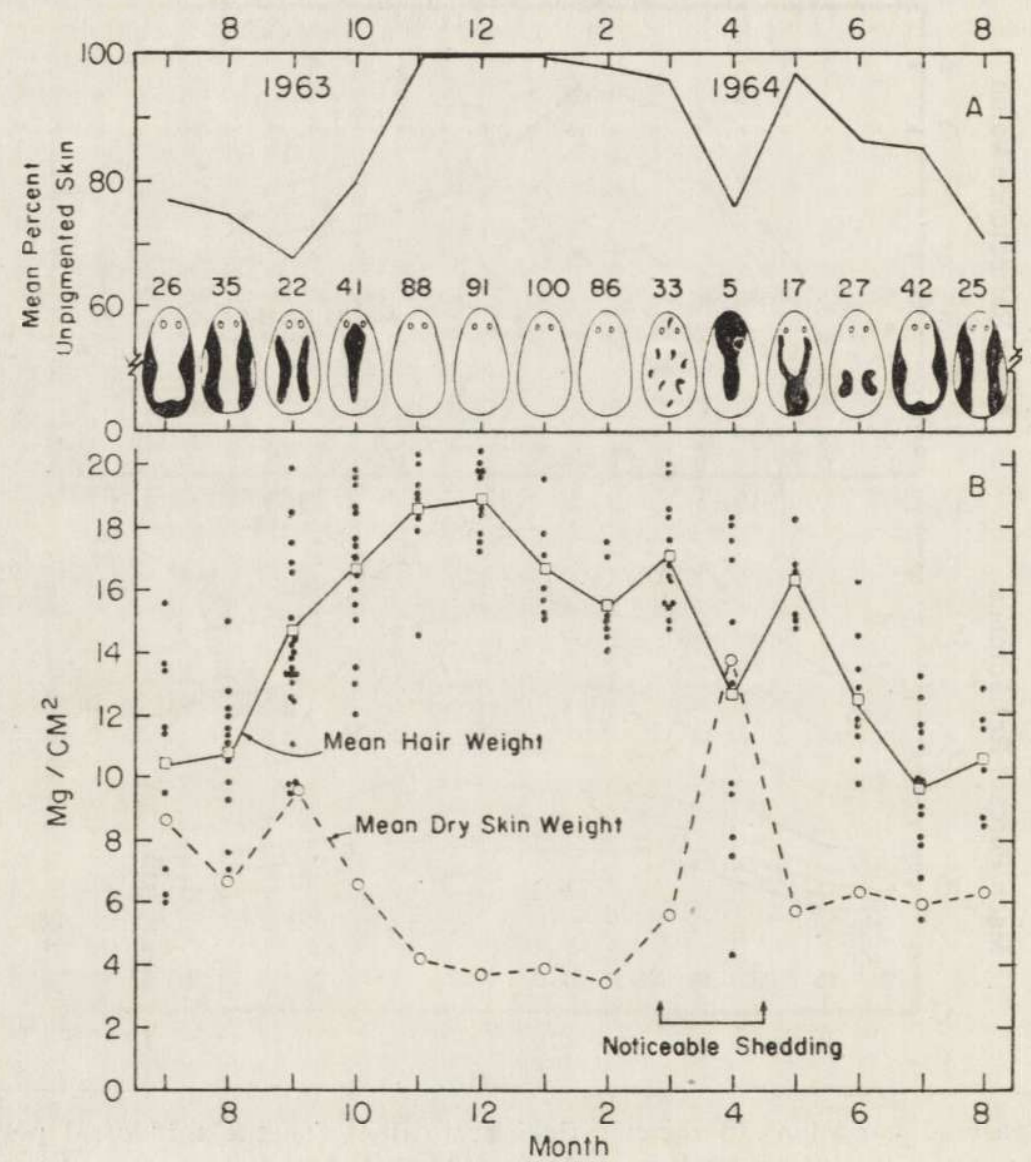

Fig. 4. Seasonal variations in pelage characteristics of Clethrionomys rutilus from College, Alaska. (A) Monthly changes in mean primeness (percent of pelt without pigmentation) of pelts. Outline drawings below primeness curve represent the predominant monthly pigmentation patterns. Darkened areas indicate regions of pigmentation. Numbers above drawings indicate the monthly incidence (percent) of completely unpigmented pelts. (B) Monthly changes in hair weight and dry skin weight of dorsal pelage. Points scattered about the mean hair weight curve represent individual hair weight values. Note the somewhat greater scatter of points during the onset of the spring molt when shedding of hair was also very noticeable. 
lengths. Discrepancies in values between the two methods of measurement for different months may have been due to different sample sizes as well as to differences inherent in the instrumentation employed.

Fur and Molt. Hair weight showed an obvious annual cycle (Fig. 4). Increase in density began between July and August and peaked in November and December. Hair weight per $\mathrm{cm}^{2}$ was significantly greater in winter than in summer $(\mathrm{P}<.01)$. There was no grossly visible evidence of hair replacement in the period from May through February, but from late February through mid-May fur shedding was very noticeable with a concomitant decline in mean hair weight per $\mathrm{cm}^{2}$. However, hair weights of individual pelage samples varied widely. Mean hair

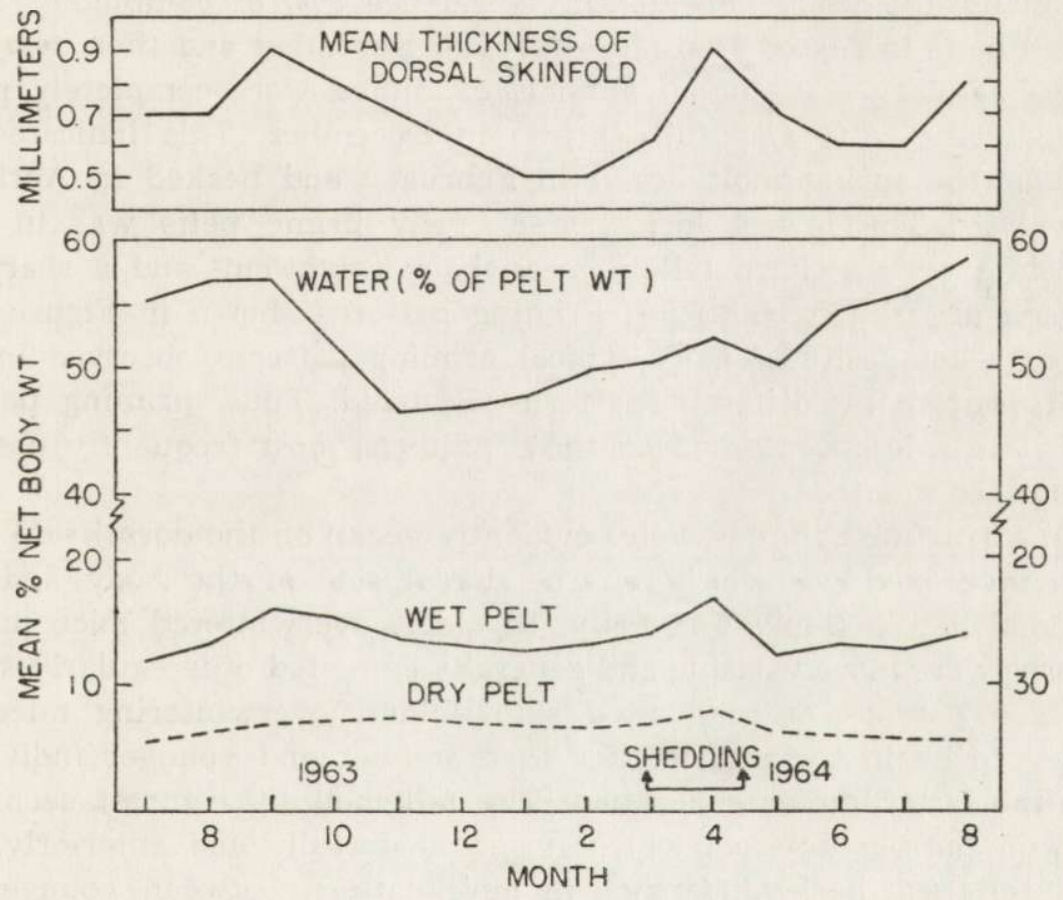

Fig. 5. Seasonal variations in dorsal skinfold thickness, wet and dry pelt weights and percent water in the pelt of Clethrionomys rutilus from College, Alaska. Sample sizes are as shown in Figure 6.

density was lowest in July, 1963 and highest in November and December, 1963; mean hair weight in November and December was $78 \%$ greater than in July. Increase in hair weight was accompanied by a decrease in skin thickness, as measured by dry weight per $\mathrm{cm}^{2}$. The plot of mean dry skin weights is the reciprocal of that for mean hair weights except for the period of rapid molt in February and March. At this time there 
was a sharp rise in absolute mean skin weight that subsided again when visible evidence of molt in the form of loose hair was no longer apparent. Increased skin weight at this time may have been due to increased vascularity resulting from circulatory adjustments accompanying molt. As shown in Figure 5, wet pelt weight, expressed as percent NBW, also increased at this time. Relative dry pelt weight showed a concomitant increase. Although skin thickness was not measured quantitatively (except as weight per $\mathrm{cm}^{2}$ ) it seemed noticeably thinner and more parchment-like in midwinter than during autumn and spring when molt was in progress.

The upper portion of Figure 4 shows typical priming patterns of pelts throughout the year. The monthly incidence $(\%)$ of completely unpigmented pelts increased from July through December and then decreased. During January skins of all animals examined were completely prime; the majority were also fully prime in December. This indicates that onset of the spring molt began in February and peaked in April and early May. The lowest incidence of fully prime pelts was in Aprii coinciding with a sharp fall in mean hair weight $/ \mathrm{cm}^{2}$ and a sharp rise in mean dry skin weight/ $\mathrm{cm}^{2}$. Priming patterns shown in Figure 4 represent a composite of more typical priming patterns observed in each month, but many different patterns occurred. Thus, priming patterns shown are inferences based on those patterns most frequently observed during each month.

The spring molt in most voles evidently began on the dorsal side of the head, proceeded posteriorly on the dorsal side of the body and then extended to the flanks and belly. In older, overwintered mice priming patterns were more variable and generally consisted of irregularly-shaped scattered patches of pigmented skin. Older, overwintering mice also seemed to begin the molt earlier than smaller and younger individuals from the last summer generation. The fall molt by contrast seemed to begin on the venter from which it spread dorsally and anteriorly. This could reflect a basic difference in molt pattern between younger and older age groups. Similar seasonal reversals of molt pattern have been observed in many species of small mammals ( $\mathrm{H}$ a n s e n, 1959; S t od a r t, 1965; Skoczeń, 1966; B roadbooks, 1968; Ling, 1970).

The curve above the primeness patterns (Fig. 4) represents monthly changes in mean primeness (percent of pelt without pigmentation) as determined by planimetry of whole pelts and pigmented areas of each pelt. This curve shows that pelts were essentially fully prime from November through January, and there was no marked change in overall primeness until rapid molting began in April. In removing pelts it also was noted that fully prime skins in midwinter were quite losse in 
contrast to more tightly adhering skins in various stages of primeness at other seasons.

Pelt Weight and Skinfold Thickness. Relative pelt weight showed an annual cycle (Fig. 5) with peaks in autumn and spring. Parallel peaks in dorsal skinfold thickness occurred which may indicate that weight increases were correlated with changes in amount of subcutaneous fat. Figure 6 shows that a rise in the mean white fat index
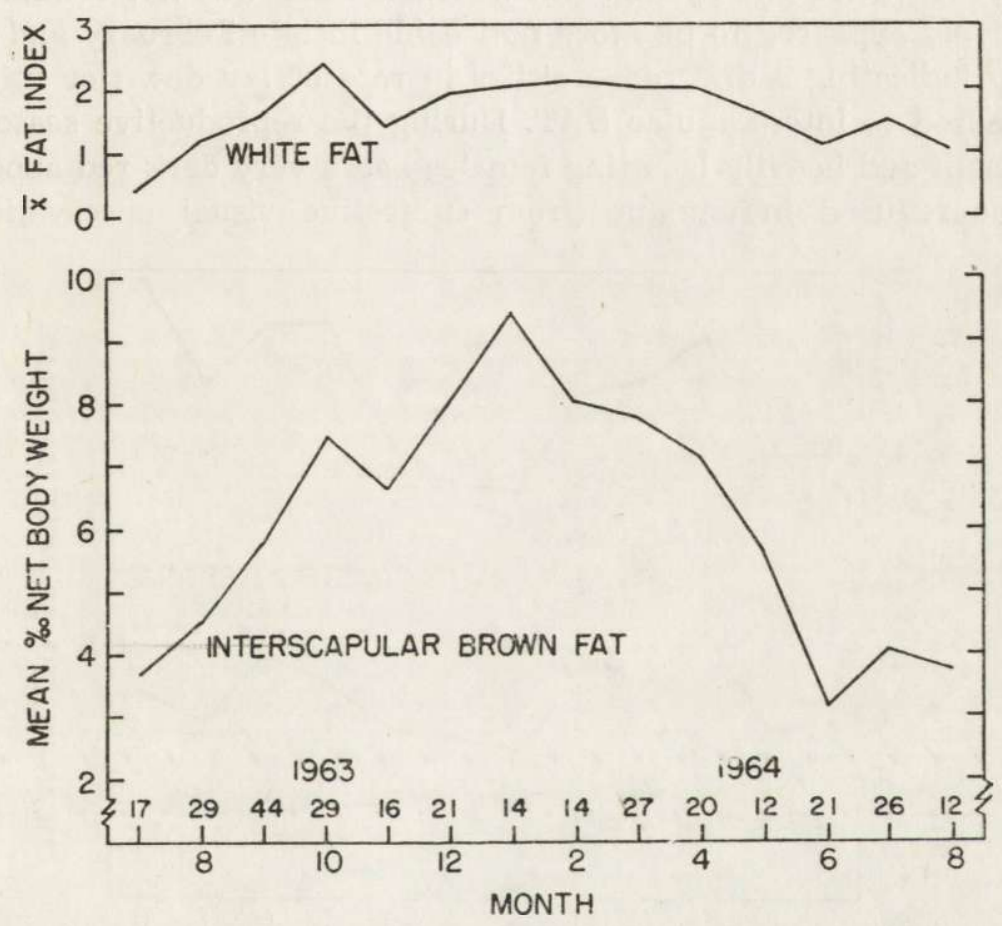

Fig. 6. Seasonal variations in relative weight of interscapular brown fat and in the index of white fat in Clethrionomys rutilus from College, Alaska. Sample sizes are indicated above each month.

in autumn paralleled the increase in dorsal skinfold thickness, but the fat index was not evident in spring. The observed increase in skinfold thickness in spring may have been due largely to an increased percentage of water in the pelt (Fig. 5), especially during the rapid molt period.

\section{Energy Stores}

Relative interscapular $B A T$ weights increased strikingly from autumn to midwinter (Fig. 6) followed by a decline from late winter into summer. 
The increase in mass of $B A T$ relative to $N B W$ was $154 \%$ from July, 1963 to January, 1964 . The late winter to summer decline in $B A T$ was probably much greater than indicated by relative interscapular $B A T$ since $\mathrm{D}$ id ow \& $\mathrm{H}$ a y w a rd (1969) found an especially noticeable decrease in thoracic and abdominal BAT as compared to interscapular BAT. The white fat index rose in autumn but fell sharply at the onset of winter after which it again rose to a somewhat lower level and remained relatively constant throughout winter and spring. Intrathoracic $B A T$ was not estimated but subjectively appeared to be more noticeable in late February and March, possibly indicating a difference either in rate of lay down or utilization as compared to interscapular $B A T$. During the reproductive season $B A T$ in pregnant and heavily lactating females had a very dark red appearance and was reduced in amount (from subjective visual observations) as

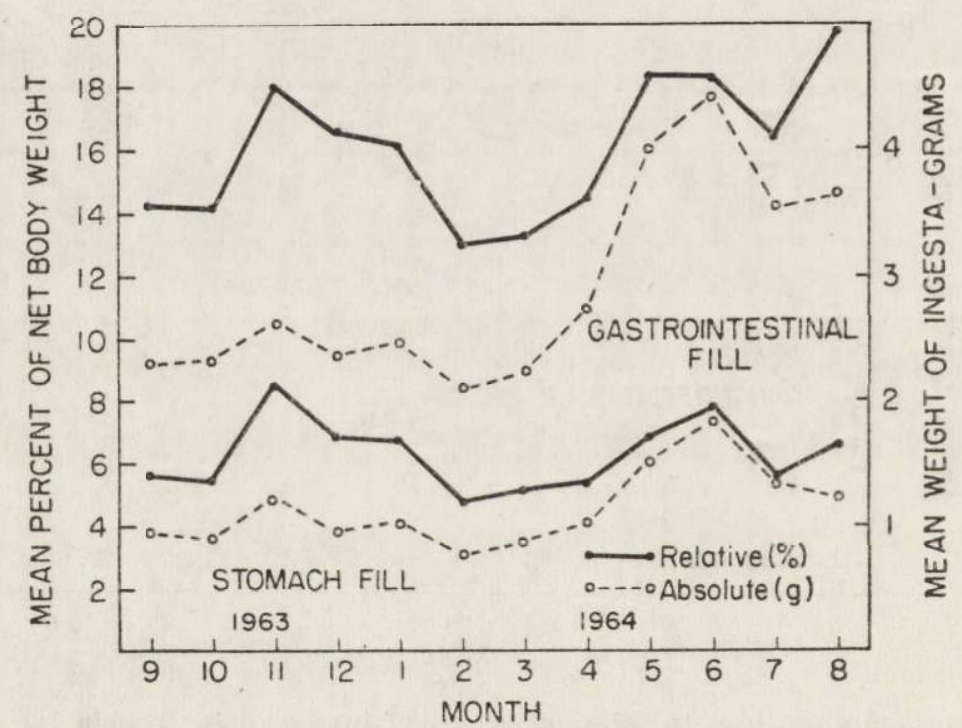

Fig. 7. Seasonal variations in stomach and gastrointestinal fill of Clethrionomys rutilus from College, Alaska. Sample sizes are as shown in Figure 6.

compared to more brownish and relatively large deposits in males and nonpregnant or nonlactating females. Thus BAT may possibly serve as an important energy source during lactation and embryonic development.

Stomach and gastrointestinal fill measurements provide some idea of seasonal changes in energy intake. Daily or hourly intakes were not measured so that monthly changes in amounts of ingesta reflect mainly changes in appetitive behavior which may either anticipate or parallel seasonal energy reguirements. Since voles were provided with food and 
water ad lib. for about 24 hours before autopsy, weights of ingesta do not represent actual weights that might be recorded from freshly caught voles but do represent changes in ingestive behavior. Figure 7 shows that ingestion increased in autumn and again in spring. Trends are similar when data are expressed either relatively in percent $N B W$ or absolutely in grams.

\section{DISCUSSION}

The northern red-backed vole, Clethrionomys rutilus, faces a severe struggle against cold and undernutrition in the harsh winter environment of its subarctic home. The rigorousness of its environment is attested to by the "die-off « by midwinter of nearly all but the youngest generations born in late summer and autumn (Fig. 1). A serious winter population decline in this species in 1965 in northern Canada was attributed to exposure to low subnivean temperatures ( $\mathrm{Fuller}$, Steb bins \& Dyke, 1969). Pelage insulation and energy reserves in the form of brown and white fat play an important role in this seasonal drama of survival.

The present study has shown that the northern red-backed vole undergoes marked seasonal changes in color and density of coat. The summer coat is dull and sparse compared to the bright and dense winter one. Pigmentation changes of this sort may be due to seasonal reduction or absence of the enzyme tyrosinase, an inactive follicle generation in summer, changes in endocrine gland activity and other factors ( $\mathrm{Ling}$, 1970; A l - K hat e e b \& J o hns on, 1971a, 1971c). Changes in gonadal and adrenal weights, and presumably their secretions also, of red-backed voles (S e a lander, 1967) were similar to those observed by A l- Khateeb \& Johnson in Microtus agrestis. They found that testosterone affected hair density and also noted that increased adrenal secretion encouraged loss of hair. Furthermore, there may be some thermal advantage in a lighter pelage at low temperatures and conversely in a darker pelage at high temperatures in relation to heat conservation and radiant energy absorbtion as shown experimentally by $\mathrm{Stullken}$ \& Hiestand (1953) and Hamilton \& Heppner (1967). However, $\mathrm{Ha} \mathrm{m} \mathrm{mel} \mathrm{(1956)} \mathrm{and} \mathrm{others} \mathrm{have} \mathrm{questioned} \mathrm{the} \mathrm{thermoregulatory}$ role of pelage color based on measurements of radiation from white and black coats.

As shown in Figure 8, hair density and reflectance of the pelage are well correlated. At a representative wave length of $640 \mathrm{mu}$ higher mean reflectance values observed in winter animals were associated with greater mean hair weights per unit of surface area. Mean skin surface 
areas of voles in different months were calculated from mean net body weights observed in these same months (S e a land e r, 1966). Figure 9 shows that the mean total surface area declined and reached a low point in midwinter when hair weight per $\mathrm{cm}^{2}$ was greatest. Despite some insulative advantage to the vole of reduction in total surface area along with reduction of body weight in winter, the surface area in $\mathrm{cm}^{2} / \mathrm{g} \mathrm{NBW}$ for voles captured in July, 1963 was 2.58 as compared to 2.87 for voles captured in December, 1963. However, the striking increase of $78 \%$ in hair weight from July to December more than compensated for the small increase in surface area per unit of body mass. G ó r e c k i (1966) under laboratory conditions found that the insulation index of wild C. glareolus

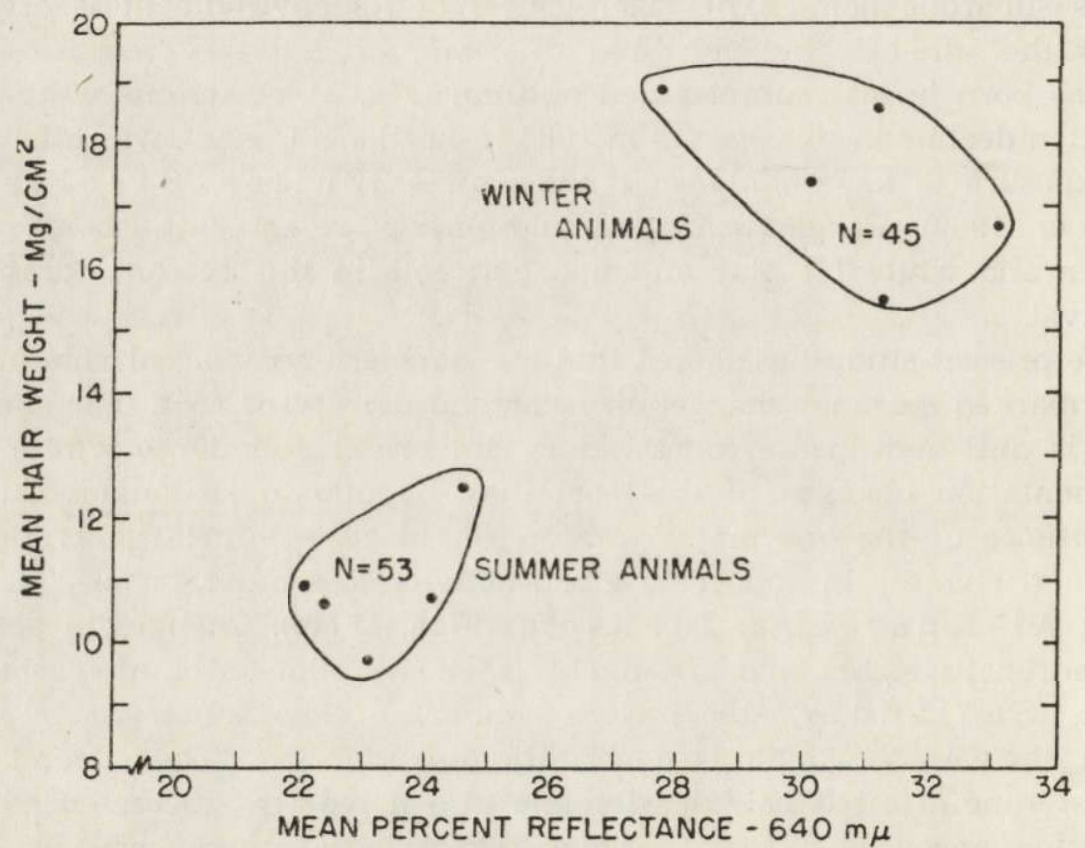

Fig. 8. Relation between mean hair weight and reflectance of the middorsal pelage of Clethrionomys rutilus from College, Alaska in summer and winter.

averaged $12 \%$ higher in winter than summer animals. Thus in winter when subjected to the most severe cold stress the vole compensates for a relative increase in surface area proportional to mass by increased pelage density, fat reserves and behaviorally through decreased activity, nest protection, social temperature regulation and possibly torpor. Late summer and fall generations seem to be successful in evading the full impact of winter temperatures in the above mentioned ways, but apparently very few individuals from older generations survive to breed again 
in spring. In summer voles are most active and presumably metabolize at the highest rate (Pearson, 1962; Schwarz et al., 1964) when body surface area is lowest in proportion to mass. This favorable ratio of surface to mass probably aids them to conserve heat loss and maintain thermogenic balance with a lower pelage density and lesser fat reserves despite more energy expenditure for reproduction and growth. As Barnett \& Mount (1967) point out, heat input per unit body weight required to maintain body temperature falls progressively with increase in body size which is a reflection of the familiar "surface law ".

In species that undergo pronounced seasonal molts pelage reflectivity measurements may have some predictive value with respect to stage of molt and degree of pelt primeness. Conceivably in species with commercially valuable pelts such measurements might be used to grade pelts or to determine the optimum period for harvesting.

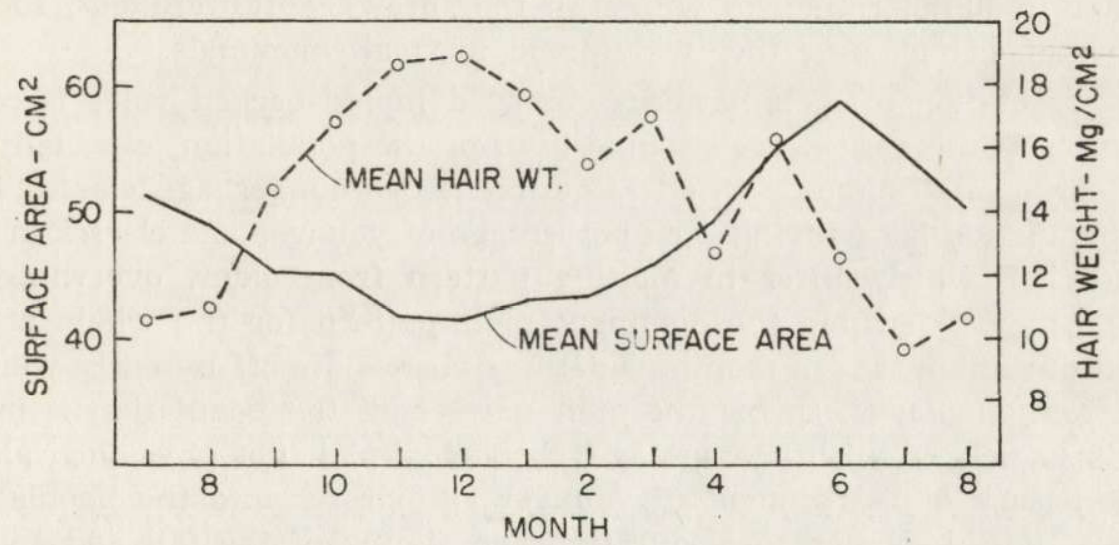

Fig. 9. Seasonal changes in mean hair weight and total body surface area of Clethrionomys rutilus from College, Alaska. Sample sizes used for calculation of mean monthly surface areas are shown in the seasonal weight curve (S e a l a nder, 1966) and do not correspond to sample sizes on which mean hair weights are based which are approximately one-half those used to determine mean monthly weights.

In its windless subnivean winter environment a dense pelage would provide the vole with comparatively greater thermal protection than in other seasons when it may be exposed to wind, even though of low, ground-level velocities. T r e g e a r (1965) observed that in various species of mammals with less than 1,000 hairs $/ \mathrm{cm}^{2}$, an 8 -mph wind penetrated deep into the fur whereas at higher pelage densities there was very little penetration even with an $18-\mathrm{mph}$ wind. He found that heat loss through dense fur is convectional and invariant whereas that through sparse fur was both radiative and convectional with the latter greatly increased by wind. 
Skin thickness (weight) varied inversely with hair density (weight) in colder months of the year (Fig. 4). The advantage to the vole is not readily apparent since the insulating characteristics of the integument are proportional to its thickness and a thin skin would provide less thermal insulation in a cold than a warm environment. B a r n e t $t$ (1959, 1965) observed the same phenomenon in mice acclimated to $-3^{\circ} \mathrm{C}$ as compared to the same strain acclimated to $21^{\circ} \mathrm{C}$, but he found that the reduced thermal efficiency of the skin itself was more than made up for by the overall increase in insulation resulting from the concomitant increase in hair weight. The thickness of skin required to provide adequate insulation to a vole in winter, hair density remaining constant, might very well completely immobilize it for all practical purposes (K le i b e r, 1947). Thus increase in fur density is a more logical solution to the problem. B or ow ski (1968) observed that skin thickness was much greater in summer than in winter in the shrew, Sorex araneus, so the phenomenon may be rather widespread in small mammals.

Interpretation of molt patterns observed in red-backed voles is complicated by the shifting age composition of the population, especially. in late spring and summer when recruitment of younger age classes into the population is occurring. The percentage of younger age classes in the population, which differ in molting pattern from older, overwintered adults, may determine the dominant molt pattern for the whole population during any given month. Older age classes die off by early winter, and from then until spring the molt pattern of the population is more nearly correlated with average age, chronological if not physiological, as there is lack of recruitment of younger age classes into the population at this time. In general the duration and timing of the fall and spring molts in C. rutilus were very similar to those in the snowshoe hare near College, Alaska (O' F a r r ell, 1965) which suggests daylength as the main factor precipitating the molt, possibly mediated through the pineal gland hormone, since it is a seasonal factor that remains constant from year to year ( $\mathrm{Ling}, 1970$ ). Shorter days plus lower temperatures determine the timing of the autumn molt. Longer days with higher temperatures determine the onset of the spring molt, and natural plant estrogens in spring foods also may stimulate reproduction which exerts a modifying effect on growth rate and density of hair ( $\mathrm{H}$ a $\mathrm{rt}, 1964$; Pinter, 1968; A l-Khate eb \& Johns on, 1971c).

Mean hair weight was also correlated with amount of interscapular $B A T$ (Fig. 10). Figure 6 shows that $B A T$ underwent a striking increase from autumn to midwinter. The thermogenic role of $B A T$ is well established (S m it h \& H or w it z, 1969) and it together with increased peláge density in winter may provide the margin of energy needed for 
survival. BAT peaked in January when energy needs are greatest and temperatures coldest (S e a l a nd e r, 1966). Similar seasonal variations in weight of BAT have been noted in other small mammals ( $\mathrm{G}$ il b e r t \& Page, 1968; Didow \& Hayward, 1969; Hiss a \& Tarkk o$\mathrm{n}$ e $\mathrm{n}, 1969)$. Without doubt this tissue is importantly involved in seasonal acclimatization of red-backed voles and other small mammals in northern regions. The inverse relationship of $B A T$ mass to air temperature observed in C. rutilus, like that noted in the red squirrel by A l e k s i u k (1971), indicates that this tissue plays an important part in its thermogenic requirements. However, in late winter and spring the gradual decline in

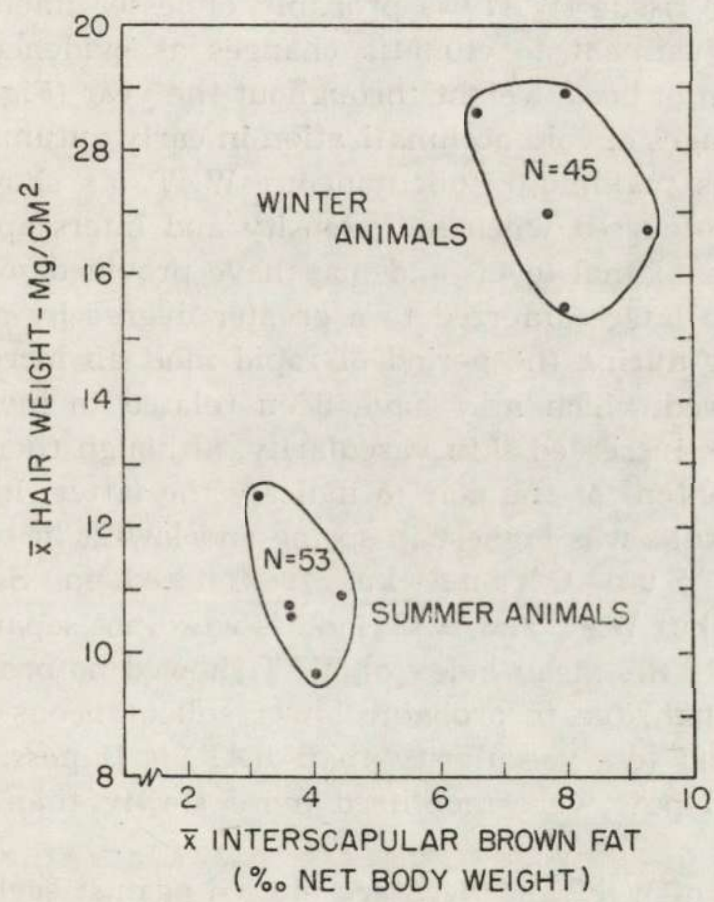

Fig. 10. Relation between mean hair weight and mean relative interscapular brown fat weight of Clethrionomys rutilus from College, Alaska in summer and winter.

relative mass of BAT in C. rutilus may indicate that its thermoregulatory role is of less importance due to attainment of adequate pelage insulation and more efficient conservation of heat loss resulting from social temperature regulation and nest protection (S e a l a n d er, 1952; G ę b c z y ński， 1969; Gębczyńska \& Gębczyński, 1971). In addition an adequate snow cover at this time buffers against low temperatures above the snow and provides a warmer subnivean microclimate. Didow \& $\mathrm{H}$ a y w a r d (1969) arrived at similar conclusions from observations made Acta theriol. 2 
on seasonal variations in $B A T$ in the meadow vole, Microtus pennsylvanicus. They also suggested that voles may employ the additional strategy of torpor to reduce their thermogenic requirements in winter. Many small mammals are now known to enter into torpor at frequent intervals during cold winter days ( $\mathrm{H} \mathrm{uds}$ on, 1967; M o r hardt, 1970; $\mathrm{St}$ e bb in s, 1971), and it is possible that $C$. rutilus may also use this means of evading winter food shortages. However, F ulle r et al. (1969) noted that $C$. rutilus remained active throughout the winter in northern $\mathrm{Ca}-$ nada in contrast to Peromyscus maniculatus which frequently entered into torpor.

White adipose tissue (WAT) is probably of lesser importance in overall seasonal adjustment to climatic changes as evidenced by its more constant fraction of body weight throughout the year (Fig. 6), except that during initial stages of cold acclimatization in early autumn, before pelage density becomes maximum subcutaneous WAT, as shown by skinfold measurements, occurred when hair density and interscapular $B A T$ were both far below maximal levels and may have provided some of the insulative protection later conferred to a greater degree by a denser pelage. Again, in spring during the period of rapid molt an increase in skinfold thickness occurred which may have been related to increased subcutaneous WAT plus increased skin vascularity, although there was no sharp rise in water content of the pelt to indicate the latter. In China relative fatness of $C$. rutilus was highest in spring and lowest in summer $(\mathrm{H} \mathrm{s}$ i a Wu-ping \& Sun-Chang-lu, 1963, cited in Sawicka-Kap u s ta, 1968), but $W A T$ and $B A T$ indices were not separately stated. In the present study the mean index of WAT showed no pronounced change in spring, although due to probable lower subcutaneous than body core temperatures and less vascularity than $B A T$, it is possible that subcutaneous WAT depots were mobilized more slowly than more centrally located WAT.

When indices of WAT and BAT are plotted against each other (Fig. 11) it is evident that total fat depots of winter as compared to summer animals are distinctly greater. Voles in winter probably depend more upon energy from fat coupled with a decreased rate of heat loss to meet increased metabolic demands (Johnson \& Groepper, 1970) than upon an increased ingestive rate which apparently may be of greater importance in autumn and spring when neither adipose tissue nor hair density are at maximum levels. It also is possible, however, that changes in ingestive rates may reflect altered digestive efficiencies in different seasons depending upon the nutritive quality of the natural diet which in winter, at least, is definitely poorer (M ille r, 1954; G ó r e c ki \& Gę b czyńska, 1962; P e a r s on, 1962; W a t ts, 1968). In autumn 
climatic stress before a protective snow cover has arrived and in spring stresses associated with reproduction may be severe ( $\mathrm{S}$ e a l a n d e r, 1966). W o łk (1969) in Poland found that the shrew, Sorex araneus, markedly increased its food intake in spring with the approach of the reproductive season. Absolute food intake was only $9.7 \%$ higher in winter than in summer, although on a per gram body weight basis winter food consumption was $62.1 \%$ vs $44.6 \%$ in summer under laboratory conditions. In the present study the mean weight of ingesta in the gastrointestinal tract more than doubled from late winter to late spring, an increase in appetitive behavior which probably reflects in large measure increased energy demands stemming from reproductive activities and embryonic growth.

The relative weight of the wet pelt paralleled the percent water in the pelt whereas relative dry pelt weight remained quite constant through-

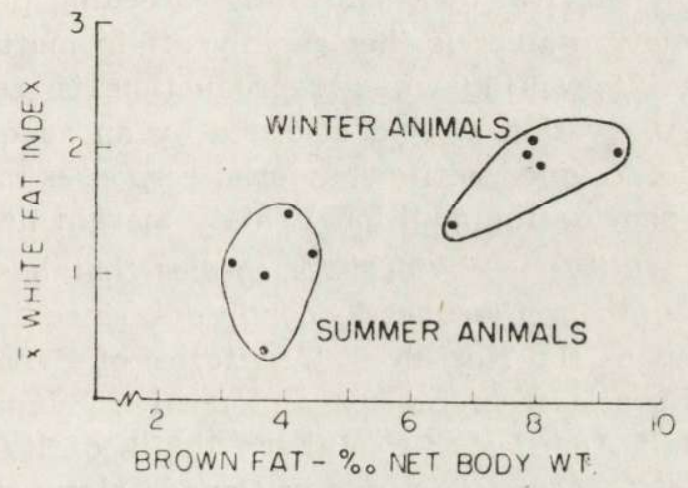

Fig. 11. Relation between indices of white fat and mean relative brown fat weights of Clethrionomys rutilus from College, Alaska in summer and winter. Sample sizes are the same as shown in Figure 10.

out the year, except during the rapid molt period in spring when a small increase occurred. B a k e r (1960) noted a significant increase in total water content of the skin in laboratory rats, Rattus norvegicus, after about 50 days acclimatization to cold $\left(1^{\circ} \pm 2^{\circ} \mathrm{C}\right)$. In cattle dehydration produced by withholding drinking water for three days reduced water content of the skin by approximately $5 \%$ (B i a n c a, 1968). Maximum differences in skin water content observed in C. rutilus were about $10 \%$. Whether low skin water content in winter was related to a less succulent diet (S e a l a nd er, 1969) and nonavailability of water, except as ice and snow, is conjectural. The increase in dry pelt weight in spring could have been due to rapid hair follicle growth with increased protein synthesis while old hair was still in the process of replacement. Seasonal 
changes in relative pelt weight and skinfold thickness were most closely related to the fall and spring molting periods. However, relative pelt weights during summer did not reflect changes in water content of the skin.

The process of seasonal acclimatization in C. rutilus, involves a number of concomitant adjustment which are metabolic or insulative in nature, Some of these adjustments have been considered previously (S e a l a n d e r, 1966, 1967, 1969; M orris on, R os enmann \& S eala nder, 1966; S e a l a nder \& B i ckerst a f f, 1967). Adjustments noted in the present study which prepare the vole for survival through severe winter weather and for coping with increased energy demands in the reproductive season include increased pelage insulation and fat reserves from autumn into winter and an increased ingestive rate in spring. These adjustments together with others previously reported evidently are sufficient to allow survival of a substantial breeding population, largely composed of immature animals that rapidly attain maturity under favorable conditions, into spring when reproduction is resumed after the winter suspension. Evasion of cold afforded by an adequate snow depth and nest protection coupled with behaviorial responses including huddling and torpor may provide the additional safety margin needed.

Clethrionomys rutilus is obviously a species that has undergone successful adaptation to arctic-subartic conditions since its distribution in North America spans the Northwest Territories of Canada west through Alaska and in Eurasia from Siberia and northern Japan and China to Norway. In North America the southern limits of its range meet the northern limits of $C$. gapperi's range in Canada along the southern edge of the Northwest Territories and northern British Columbia.

Fuller (1969) on the basis of breeding activities postulated that C. rutilus is fundamentally more cold tolerant than C. gapperi. From evidence in the literature and my own observations I suggest that $C$. rutilus is physiologically better adapted than C. gapperi for low winter temperatures with limited food, and possibly its southern range limits could be defined by an isothermal line. In Europe and Asia C. rutilus also dominates the arctic-subarctic regions being replaced in more southern regions by $C$. rufocanus and C. glareolus. Some of the ecological factors that determine such distributional limits have been investigated by Pearson (1962), Š varc et al. (1968) and others.

Acknowledgements: This study was carried out under a Public Health Service special fellowship (1-F3-GM-20, 025) and was assisted by a grant from the National Science Foundation (GB 890). Supported in part by Public Health Service Grant No. GM-10402 to the Laboratory of Zoophysiology, Institute of Arctic Biology, University of Alaska. The author also extends his appreciation to the Savannah River 
Ecology Laboratory, Aiken, South Carolina for use of the Bausch and Lomb Spectronic 505 Recording Spectrophotometer.

\section{REFERENCES}

1. Aleksiuk M., 1971: Seasonal dynamics of brown adipose tissue function in the red squirrel (Tamiasciurus hudsonicus). Comp. Bioch. Physiol., 38A: 723731

2. Al-Khateeb A. \& Johnson E., 1971a: Seasonal change of pelage in the vole (Microtus agrestis) I. Correlation with changes in the endocrine glands. Gen. Comp. Endocrinol., 16: 217-228.

3. Al-Khateeb A. \& Johns on E., 1971b: Seasonal changes of pelage in the vole (Microtus agrestis) II. The effect of daylength. Gen. Comp. Endocrinol., 16: $229-235$.

4. A $1-\mathrm{Kh}$ atee b A. \& Johns on E., 1971c: Seasonal change of pelage in the vole (Microtus agrestis) III. The role of the endocrine system. Gen. Comp. Endocrinol, 16: 236-240.

5. B a k e r D. G., 1960: Electrolyte metabolism in the rat exposed to a low environmental temperature. II. Can. J. Biochem. Physiol., 38: 205-211.

6. Barnet S. A., 1959: The skin and hair of mice living at a low environmental temperature. Quart. J. exp. Physiol., 44: 35-42.

7. Barnett S. A., 1965: Adaptation of mice to cold. Biol. Rev., 40: 5-51.

8. Barnett S. A. \& Mount L. E., 1967: Resistance to cold in mammals. [In "Thermobiology« ed. A. S. R o s e]. Academic Press: 412-467. London and New York.

9. Bianca W., 1968: Effects of water deprivation on the water content of cattle skin. Int. J. Biometeor., 12: 153-157.

10. Borowski S., 1968: On the moult in the common shrew. Acta theriol., 13: $483-498$.

11. Broadbooks H. E., 1968: Molts of the yellow-pine chipmunk, Eutamias amoenus. Am. Midl. Nat., 79: 364-387.

12. Didow L. A. \& Hayward J. S., 1969: Seasonal variations in the mass and composition of brown adipose tissue in the meadow vole, Microtus pennsylvanicus. Can. J. Zool., 47: 547-555.

13. Fulle r W. A., 1969: Changes in numbers of three species of small rodent near Great Slave Lake, N. W. T. Canada, 1964-1967, and their significance for general population theory. Ann. zool. Fennici, 6: 113-144.

14. Fulle r W. A., Ste b bins L. L. \& Dy k e G. R., 1969: Overwintering of small mammals near Great Slave Lake northern Canada. Arctic, 22: $34-55$.

15. Gębczyński M., 1969: Social regulation of body temperature in the bank vole. Acta theriol., 14: 427-440.

16. Gębczyńska Z. \& Gębczyński M., 1971: Insulating properties of the nest and social temperature regulation in Clethrionomys glareolus ( $\mathrm{S} \mathrm{c} \mathrm{h} \mathrm{r} \mathrm{e} \mathrm{be} \mathrm{r).}$ Ann. zool. Fennici, 8: 104-108.

17. Gilbert R. \& Page E., 1968: L'acclimatation saisonniere chez le rat. Rev. Can. Biol., 27: 241-254. (In French with English summ.).

18. Górecki A., 1966: Metabolic acclimatization of bank voles to laboratory conditions. Acta theriol., 11: 399-407.

19. Gór ecki A. \& G ęb czyńska Z., 1962: Food conditions for small rodents in a deciduous forest. Acta theriol., 6: 275-295. 
20. Haitlinger R., 1965: Morphological analysis of the Wroclaw population of Clethrionomys glareolus (S c h re be r, 1780). Acta theriol., 10: 243-272.

21. Hamilton W. J., III. \& Heppner F., 1967: Radiant solar energy and the function of black homeotherm pigmentation: an hypothesis. Science, 155: 196197.

22. H a m mel H. T., 1956: Infrared emissivities of some Arctic fauna. J. Mammal., 40: 205-213.

23. H a n s e n R. M., 1959: Aspects of coat color in young varying lemmings. J. Mammal., 40: 205-213.

24. H a r t J. S., 1964: Geography and season: Mammals and birds. [In "Adaptation to environment«, Handbook of Physiology]. Amer. Physiol. Soc.: 295-321. Washington.

25. Hissa R. \& Tarkonnen H., 1969: Seasonal variations in brown adipose tissue in two species of voles and the common shrew. Ann. zool. Fennici 6: $443-447$.

26. $\mathrm{Huds}$ on J. W., 1967: Variations in the patterns of torpidity of small homeotherms. [In "Mammalian hibernation III ]. Oliver \& Boyd: 30-46. Edinburgh and London.

27. Johnson D. R. \& Groepper K. L., 1970: Bioenergetics of north plains rodents. Am. Midl. Nat., 84: 537-548.

28. Kleiber M., 1947: Body size and metabolic rate. Physiol. Rev., 27: 511-541.

29. Ling J. K., 1970: Pelage and molting in wild mammals with special reference to aquatic forms. Quart. Rev. Biol., 45: 16-54.

30. Low e V. P. W., 1971: Root development of molar teeth in the bank vole (Clethrionomys glareolus). J. Anim. Ecol., 40: 49-61.

31. M a zák V., 1963: Notes on the dentition in Clethrionomys glareolus $\mathrm{Schre-}$ ber, 1780 in the course of postnatal life. Säugetierk. Mitt., 11: 1-11.

32. Miller R. S., 1954: Food habits of the wood mouse, Apodemus sylvaticus (L i n n e, 1758), and the bank vole, Clethrionomys glareolus ( $\mathrm{S} \mathrm{ch} \mathrm{re} \mathrm{be} \mathrm{r,} \mathrm{1780)}$ in Wythnam Woods, Berkshire. Säugetierk. Mitt., 2: 109-114.

33. M orhardt J. E., 1970: Body temperatures of white-footed mice (Peromyscus sp.) during daily torpor. Comp. Bioch. Physiol., 33: 423-439.

34. Morrison P., Rosenmann M. \& S e a lander J. A., 1966: Seasonal variation of myoglobin in the northern red-backed vole. Am. J. Physiol., 211: 13051308.

35. O'F a r r el1 T. P., 1965: Home range and ecology of snowshoe hares in interior Alaska. J. Mammal., 46: 1-58.

36. Pears on A. M., 1962: Activity patterns, energy metabolism, and growth rate of the voles Clethrionomys rufocanus and C. glareolus in Finland. Ann. Zool. Soc. »Vanamo«, 24: 1-58.

37. Pinter A. J., 1968: Hair growth responses to nutrition and photoperiod in the vole, Microtus montanus. Am. J. Physiol., 215: 828-832.

38. Prychodko W., 1951: Zur Variabilität der Rötelmaus Clethrionomys glareolus in Bayern. Zool. Jb., 80: 482-506.

39. Pucek Z., Ryszkowski L. \& Z j ja J., 1969: Estimation of average length of life in bank vole, Clethrionomys glareolus (S c hreber, 1780). [In $»$ Energy flow through small mammal populations«, eds. K. Petrusewicz \& L. R y s z k ow s k i]. Państw. Wyd. Nauk.: 187-201. Warszawa.

40. Sawicka-Kapusta K., 1968: Annual fat cycle of field mice, Apodemus flavicolis ( $\mathrm{M} \mathrm{e} \mathrm{lchior,} \mathrm{1834).} \mathrm{Acta} \mathrm{theriol.,} \mathrm{13:} \mathrm{329-339.}$ 
41. Schwarz S. S., Pokrovski A. V., Istchenko V. G., Olenjev V. G., Ovtschinnikova N. A. \& Piastolova O. A., 1964: Biological peculiarities of seasonal generations of rodents with special reference to the problem of senescence in mammals. Acta theriol., 8: 11-43.

42. S e a la nd e r J. A., 1952: The relationship of nest protection and huddling to survival of Peromyscus at low temperature. Ecology, 33: 63-71.

43. Se al ander J. A., 1966: Seasonal variations in hemoglobin and hematocrit values in the northern red-backed mouse, Clethrionomys rutilus dawsoni (M e rr i a m), in interior Alaska. Can J. Zool., 44: 213-244.

44. S e a l a n der J. A., 1967: Reproductive status and adrenal size in the northern red-backed vole in relation to season. Int. J. Biometeor., 11: 213-220.

45. S e a lander J. A., 1969: Effect of season on plasma and urinary proteins of the northern red-backed vole, Clethrionomys rutilus. Physiol. Zoöl., 42: 275287.

46. Se a l a nder J. A. \& Bickerstaff L. K., 1967: Seasonal changes in reticulocyte number and in relative weights of the spleen, thymus, and kidneys in the northern red-backed mouse. Can. J. Zool., 45: 253-260.

47. Selander R. K., J ohnston R. F. \& H a milt on T. H., 1964: Colorimetric methods in ornithology. Condor, 66: $491-495$.

48. Sk oczen S., 1966: Seasonal changes of the pelage in the mole, Talpa europea Li n n a e u s, 1758. Acta theriol., 11: 537-549.

49. Smith M. H., Blessing R. W., Carmon J. L. \& Gentry J. B., 1969: Coat color and survival of displaced wild and laboratory reared old-field mice. Acta theriol., 14: $1-9$.

50. Smith R. E. \& Horwitz B. A., 1969: Brown fat and thermogenesis. Physiol. Rev., 49: 330-425.

51. Smyth M., 1966: Winter breeding in woodland mice, Apodemus sylvaticus, and voles, Clethrionomys glareolus and Microtus agrestis, near Oxford. J. Anim. Ecol., 49: 330-425.

52. Ste b bins L. L., 1971: Seasonal variations in circadian rhythms of deer mice, in northwestern Canada. Arctic, 24: 124-131.

53. Stoddart E., 1965: A study of the biology of the wild rabbit in climatically different regions in eastern Australia. II. Seasonal changes in the pelt. CSIRO Wildl. Res., 10: 33-72.

54. Stullken D. E. \& Hiestand W. A., 1953: An experimental study of the influence of pelage pigmentation on metabolic rate and its possible relationship to body temperature control and ecological distribution. Ecology, 43: 610-613

55. Švarc S. S., Bol'šakov V. N., Olenev V. G. \& Pjastolova O. A., 1969: Population dynamics of rodents from northern and mountainous geographical zones. [In »Energy flow through small mammal populations«, eds. K. Petrusewicz \& L. Ryszkowski]. Państw. Wyd. Nauk.: 205-220.

56. Tregear R. T., 1965: Hair density, wind speed and heat loss in mammals. Am. J. appl. Physiol., 20: 796-801.

57. Viitala J., 1971: Age determination in Clethrionomys rufocanus (S unde- 。 v a 11). Ann. zool. Fennici, 8: 63-67.

58. W a t t s C. H. S., 1968: The foods eaten by wood mice (Apodemus sylvaticus) and bank voles (Clethrionomys glareolus) in Wytham Woods, Berkshire. J. Anim. Ecol., 37: 25-41.

59. Wo $1 \mathrm{k}$ E., 1969: Body weight and daily food intake in captive shrews. Acta theriol., 14: 35-47. 
60. $\mathrm{Zejda}$ J., 1961: Age structure in populations of the bank vole, Clethrionomys glareolus Schreber 1780. Zool. Listy, 10: 249-264.

61. Z e jda J., 1964: Development of several populations of the bank vole Clethrionomys glareolus $\mathrm{Schreb.,}$ in a peak year. Zool. Listy, 13: 15-30.

Accepted, November 5, 1971.

Department of Zoology,

University of Arkansas,

Fayetteville, Arkansas, USA 72701.

John A. SEALANDER

OKOEO-ROCZNE ZMIANY WIEKU, WŁASCIWOSCI UWŁOSIENIA I TKANKI TEUSZCZOWEJ U NORNIC Z ALASKI

\section{Streszczenie}

Badano około-roczne zmiany struktury wiekowej, właściwości uwłosienia i tkanki tłuszczowej u Clethrionomys rutilus dawsoni (M e riam), w okresie od lipca 1963 do sierpnia 1964 roku. Badania ṕrzeprowadzono w okolicach College na Alasce $\left(65^{\circ} \mathrm{N} 147^{\circ} \mathrm{W}\right)$.

Starsze klasy wiekowe znikają z populacji w środku zimy. Ich udział w populacji nie jest istotny aż do następnej wiosny, (maj - czerwiec). W lipcu populacja odmładza się, przez wejście młodych z miotów wiosennych, a w sierpniu większość starszych klas wiekowych (przezimki) wymiera (Ryc. 2).

Ciężar włosów był najmniejszy w lipcu $1963\left(10,0 \mathrm{mg} / \mathrm{cm}^{2}\right)$ a największy w grudniu tegoż roku $\left(18,9 \mathrm{mg} / \mathrm{cm}^{2}\right)$ - wzrastal więc o $78 \%$. Sredni ciężar suchej masy skóry był prawie odwrotny do ciężaru włosów (Ryc. 4).

Ubarwienie futerka mierzono stopniem odbicia światła o różnej długości fali. Najniższy stopień odbicia obserwowano badając ciemne futerka letnie w lipcu i sierpniu, a najwyższy odpowiadał jasnym futerkom zimowym i wiosennym w grudniu i styczniu (Ryc. 3). Jakość futerka była najwyższa od listopada do lutego, wyznaczając koniec linki jesiennej i wiosennej (Ryc. 4). Przebieg linki jesiennej i wiosennej był odwrotny. Względny ciężar świeżego futerka i grubości skóry wykazują podobny trend, ze szczytami na początku zimy i na wiosnę (Ryc. 5). Względny ciężar suchej masy futerka był raczej stały w ciągu roku, za wyjątkiem okresu gwałtownej linki wiosennej.

Względna masa tłuszczu brunatnego, w stosunku do ciężaru ciała netto, wzrasta od lipca do stycznia o $154 \%$. Indeks tłuszczu białego pozostaje względnie stały, z wyjątkiem wzrostu wczesną zimą, a więc zanim zagęszczenie włosów i tłuszcz brunatny nie osiągną maksymalnego poziomu (Ryc. 6).

Pobranie pokarmu wyrażane stopniem wypełnienia żołądka i jelit, wykazuje wy - raźny wzrost wczesną zimą i ponownie na wiosnę (Fig. 7). 